\title{
ELŻBIETA MŁYŃSKA
}

BIAŁYSTOK

ORCID 0000-0002-0501-6955

\section{EWOLUCJA KATECHEZY DOROSEYCH W DYREKTORIACH Z LAT 1971-2020}

Soborowe otwarcie Kościoła na świat dało również impuls katechezie adresowanej do wszystkich ochrzczonych. W optyce duszpastersko-katechetycznej ujęto nawet tych, którzy nie są ochrzczeni, a pragną wejść do wspólnoty Kościoła. Konstytucja duszpasterska o Kościele w świecie wspótczesnym, Konstytucja dogmatyczna o Kościele, Dekret o apostolstwie świeckich czy Dekret o działalności misyjnej Kościoła dowartościowały laikat, ale też postawiły przed nim nowe zadania. Przeglądając wymienione dokumenty soborowe można odnaleźć w nich teologiczne i eklezjalne uzasadnienie dla miejsca i roli świeckich w Kościele ${ }^{1}$, także w zaangażowaniu ewangelizacyjnym. Podjęta po Soborze refleksja nad posługą słowa zaowocowała trzema dyrektoriami Kościoła powszechnego, a są to: Ogólna instrukcja katechetyczna z 1971 roku, Dyrektorium ogólne o katechizacji z 1997 roku oraz Dyrektorium o katechizacji z 2020 roku. We wszystkich tych dokumentach wśród adresatów katechezy obok dzieci i młodzieży wymienia się osoby dorosłe.

\section{Dorosły w procesie kształtowania wiary}

Każde z dyrektoriów katechetycznych, przyjmując własne kryteria, podejmuje próbę zaprezentowania tych, którzy zaproszeni są do katechezy. Ogólna instrukcja katechetyczna w przedstawianiu grupy dorosłych przyjmuje kryterium wiekowe. Jak żaden z omawianych dyrektoriów, Instrukcja dużo miejsca poświęca młodym ludziom, przygotowującym się do życia dorosłego (OIK 82-91). Analizując ich sytuację życiową proponuje, by wychowywać młodych ludzi do odpowiedzialności związanej z wiarą oraz przygotowywać ich stopniowo do zrealizowania chrześcijańskiego

1 J. Charytański, Inspiracje soborowe w katechetyce, w: Katecheza po Soborze Watykańskim II wświetle dokumentów Kościoła, cz. 1, Warszawa 1985, s. 43. 
powołania (OIK 89). Instrukcja obok młodzieży wylicza dorosłych ${ }^{2}$, to znaczy tych, którzy osiągnęli wiek dojrzały i podejmują obowiązki w życiu społecznym, rodzinnym, zawodowym, politycznym (OIK 92-94). Z tego powodu potrzebują wsparcia w zmierzeniu się z właściwymi ich powołaniu i misji wyzwaniami. Osobną grupę stanowią ludzie starzy, którzy z racji na swoje uwarunkowania wymagają katechezy zorientowanej eschatologicznie (OIK 95).

W Dyrektorium ogólnym o katechizacji dorośli to osoby wobec których przekaz wiary uwzględnia ich doświadczenia, uwarunkowania i wyzwania. We wstępnej prezentacji dokument przedstawia trzy kategorie dorosłych, mające zróżnicowany stosunek do wiary. Mówi zatem o dorosłych wierzących, potrzebujących pogłębiania swojej wiary, dorosłych ochrzczonych, którzy potrzebują doprowadzenia do końca procesu wtajemniczenia chrześcijańskiego oraz dorosłych nieochrzczonych i potrzebujących katechumenatu. Mowa jest również o tych, którzy pochodzą z innych wyznań nie będących w pełni w komunii z Kościołem katolickim (DOK 172). Dyrektorium kontynuując myśl Instrukcji osobno poświęca uwagę katechezie ludzi młodych (OIK 184-185) i osób starszych (OIK 186-188). Ta zmiana perspektywy dająca priorytet kryterium wiary przed kryterium wieku świadczy o ewolucji myśli dotyczącej katechezy dorosłych ${ }^{3}$.

Najnowszy dokument katechetyczny podkreśla, że dzisiaj sytuacja dorosłych zasadniczo różni się od tej w przeszłości. Dorosłość nie oznacza już czasu osiągniecia stabilności, ale okres dynamicznie zachodzących zmian w życiu rodzinnym, kulturowym i społecznym, na które dorosły zobowiązany jest reagować i twórczo w nich uczestniczyć. Ta dynamika „stawania się dorosłym” wymaga stale przeformułowania wiary (DK 257). Jako kryterium kategoryzowania dorosłych uczestników katechezy w tym dokumencie przyjęto stosunek dorosłego do wiary. Zgodnie z nim Dyrektorium wymienia sześć typów ludzi. Są to dorośli wierzący, którzy chcą pogłębić wiarę, dorośli, którzy nie doprowadzili do końca chrześcijańskiego wtajemniczenia wiary, dorośli, którzy szukają kontaktu ze wspólnotą kościelną jedynie w pewnych okolicznościach życia, dorośli z innych wyznań chrześcijańskich, dorośli powracający do wiary katolickiej i nieochrzczeni, którzy potrzebują katechumenatu (DK 258). Podobnie jak w Dyrektorium ogólnym o katechizacji kategorie wiekowe dorosłych traktuje się jako zagadnienie drugorzędne (por. DK 250-256, 266-268). Natomiast nowością dokumentu jest to, że uwzględnia katechezę $\mathrm{z}$ dorosłymi znajdującymi się w szczególnych sytuacjach życiowych. Może być to katecheza z niepełnosprawnymi dorosłymi (269-272), z imigrantami (273-276),

2 J. Bagrowicz, Katecheza na poszczególne etapy życia człowieka, w: Katecheza po Soborze Watykańskim II... , cz. 1, s. 71-72; K. Misiaszek. Dorosty w procesie ewangelizacji i katechezy, w: K. Misiaszek (red.), Katecheza dorostych we wspólnocie Kościoła, Warszawa 2002, s. 132-139.

3 Por. D. Kurzydło, Koncepcja katechezy dorosłych we współczesnych dokumentach Kościoła, Warszawa 2003, s. 170-186. 
z emigrantami (277-278), z osobami zmarginalizowanymi, a m.in. przebywającymi w więzieniach (279-282).

\section{Od apostolstwa świeckich do katechezy dorosłych}

Świadomość potrzeby formacji osób dorosłych w Kościele budziła się wraz z podejmowanymi przez nie nowymi rolami w obszarze życia społecznego, gospodarczego, politycznego, kulturalnego, a w ślad za nimi nowym sposobem uczestniczenia w życiu Kościoła otwierającego się na świat. II Sobór Watykański uznał bowiem, że „Apostolstwo w środowisku społecznym jest tak dalece obowiązkiem ludzi świeckich, że inni nigdy nie mogą ich w tej dziedzinie należycie zastąpić" (DA 13). Zaangażowanie zatem świeckich, stale konfrontowanych z optyką świata w apostolstwo, dostarczało wystarczających motywów do tego, by postulować ich formację. Także sami świeccy odczuwali potrzebę formacji, która pozwalałaby im przezwyciężać rozdźwięk pomiędzy wyznawaną wiarą, a życiem codziennym. W ten tok myślenia o formacji świeckich wpisała się Ogólna instrukcja katechetyczna, widząc potrzebę katechezy dorosłych $\mathrm{z}$ racji na podejmowane przez nich zadania apostolskie (OIK 92). Ten motyw podaje dokument jako pierwszy podkreślając konieczność katechizowania dorosłych. W miarę jednak, jak rozwijana jest koncepcja katechezy dorosłych i zarysowuje się jej wizja integralna, katecheza dorosłych, postrzegana jako przygotowanie do zadań apostolskich, traktowana jest jako jedna z jej form. (DOK 176). Ostatnie Dyrektorium proponuje osobom zmierzającym do aktywnego i inspirowanego wiarą udziału wiernych w życiu społecznym katechezę o tematyce moralnej, kulturalnej lub społeczno-politycznej (DK 264). Jest to zatem nie tylko formacja do określonego zaangażowania w posługę Kościoła wobec świata, ale katecheza o charakterze ciągłym. Katecheza taka podejmuje zadanie ożywiania wiary u tych, którzy podejmują rozumny dialog ze współczesną kulturą, jak również ma pomóc w dzieleniu się wiarą i w dawaniu świadectwa poprzez apostolskie zaangażowanie (DK 261).

\section{Od adresata katechezy do podmiotu aktywnego}

Określenie podmiotu w katechezie dorosłych nastręcza niemało kłopotu, czego wyrazem jest podejście do tematu tak w dokumentach katechetycznych, jak też we współczesnej literaturze katechetycznej. Najogólniej problem rysuje się już w samych sformułowaniach dotyczących zagadnienia, a mianowicie: „katecheza 
dla dorosłych”4, „katecheza dorosłych"5 czy też „katecheza z dorosłymi”. ${ }^{6}$ Ponadto najczęstszą kategorią służącą określeniu człowieka dorosłego jest kategoria wiekowa ${ }^{7}$, co w przypadku dorosłego będącego podmiotem katechezy, nie wydaje się być kryterium priorytetowym i wystarczającym.

Punktem wyjścia w naszej refleksji nad podmiotem katechezy dorosłych jest Ogólna instrukcja katechetyczna z roku 1971, która odnosząc się do zarządzenia soborowego dekretu Christus Dominus (p. 44), zalecającego opracowanie poradników katechetycznego nauczania ludu chrześcijańskiego, włączyła się w dzieło odnowy posługi słowa Bożego w Kościele. Jej wyrazem miało być odnowienie koncepcji katechetycznej, a między innymi objęcie katechizacją nie tylko dzieci i młodzieży, ale także „stałe wychowywanie dorosłych w zakresie wiary” (OIK 9). W celu wypełnienia zadania odnowy Kościół wiązał nadzieje z wszystkimi członkami ludu Bożego (OIK 9). Niemniej jednak dokument przywołując soborową wizję Kościoła wspólnoty służb i charyzmatów (OIK 66) dorosłych, sprowadził do roli adresatów katechezy przyznając im możliwość doskonalenia katechezy (por. OIK 75). Traktowanie dorosłego jako adresata katechezy ujawnia się najbardziej w treściach dotyczących form i zadań (OIK 96-97), w których stosownie do koncepcji katechezy używa się sformułowania „katecheza dla dorosłych”. Tak więc „katecheza dla dorosłych” ma wychowywać, udzielać odpowiedzi, naświetlać relacje, budować rozumowe podstawy wiary (OIK 97).

Z kolei Dyrektorium ogólne o katechizacji z roku 1997 zbierając owoce dyskusji synodalnych z $1974^{9}$ i $1977^{10}$ roku oraz prac nad dokumentem Katecheza dorosłych we wspólnocie chrześcijańskiej, wydanego przez Międzynarodową Radę ds. Katechezy (1990) i nad Katechizmem Kościoła Katolickiego (1992), pokazuje katechezę w misji ewangelizacyjnej Kościoła, czyniąc tym samym laikat podmiotem katechizacji (DOK 230-231) ${ }^{11}$. W dokumencie zaczyna się więc mówić o „katechezie dorosłych” (por. DOK 29), co brzmi już bardziej podmiotowo, a tym samym podkreśla podmiotowość wspólnoty eklezjalnej, w całości odpowiedzialnej

\footnotetext{
4 Por. R. Chałupniak. Jaka katecheza dla dorosłych?, w: K. Misiaszek (red.), Katecheza dorosłych we wspólnocie Kościoła, Warszawa 2002, s. 88-113.

5 K. Misiaszek, Katecheza dorosłych w dokumentach Kościoła, w: Katecheza dorosłych we wspólnocie..., tamże, s. 31-48.

6 A. Offmański, Katecheza z dorosłymi realizacją kerygmatycznej misji współczesnego Kościoła, w: Katechetyk i wychowawca, Ksiega jubileuszowa dedykowana ks. prof. Kazimierzowi Misiaszkowi SDB, Warszawa 2019, s. 75.

7 A. Kiciński, Dorosty jako podmiot katechezy, w: Katecheza dorostych we wspólnocie..., tamże, s. $141-158$.

8 K. Misiaszek. Katecheza dorosłych w dokumentach Kościoła, w: K. Misiaszek (red.), Katecheza dorostych we wspólnocie Kościoła, Warszawa 2002, s. 35.

9 Opublikowane w adhortacji Evangelii nuntiandi w 1975 roku.

10 Opublikowane w Orędziu do Ludu Bożego w 1977 i w adhortacji Catechesi tradendae w 1979 roku.

11 Por. J. Charytański, Katechizacja jako forma ewangelizacji (Synod Biskupów 1974), w: Katecheza po Soborze Watykańskim II ..., cz. 1, s. 194-195, 203-204.
} 
za dzieło katechezy (Por. Cz. III Orędzie do Ludu Bożego, CT 43, 62). Jak przypomina Orędzie posynodalne: „Wszyscy chrześcijanie, na mocy sakramentów chrztu i bierzmowania, są powołani do głoszenia Ewangelii i do troszczenia się o wiarę braci w Chrystusie..." (OLB 12). W adhortacji Catechesi tradendae z kolei czytamy, że „wspólnota chrześcijańska nie może prowadzić katechezy stałej z pominięciem bezpośredniego udziału dorosłych, zarówno tych, którzy w niej uczestniczą, jak i tych, którzy ja organizują" (CT 43). W nawiązaniu do wymienionych dokumentów Dyrektorium ogólne podkreśla, że za katechezę jest odpowiedzialna cała wspólnota chrześcijańska „Z uwzględnieniem odpowiedzialności każdego członka wspólnoty” (DOK 220). Tak więc dorośli jako część ludu Bożego, potrzebując katechezy, a jednocześnie ponosząc za nią odpowiedzialność, stanowią o podmiocie katechezy. Mimo takiego kierunku myślenia, w Dyrektorium ogólnym dorosłego ustawia się w pozycji adresata katechezy wymienianego obok dzieci i młodzieży (DOK 33). Podobnie dokument mówi o celach i zadaniach „katechezy dla dorosłych” (przed DOK 175), w czym kontynuuje myśl zaczerpniętą z Instrukcji (OIK 97)

Zupełnie inaczej sprawa wygląda w Dyrektorium o katechizacji z 2020 roku. Jako efekt ponownego odczytania natury i celu katechezy najnowszy dokument katechetyczny Kościoła powszechnego uznaje istotne znaczenie wspólnoty chrześcijańskiej jako miejsca rozwoju życia wiary. O ochrzczonych zaś mówi, że w swej godności dzieci Bożych wszyscy wierzący są aktywnymi podmiotami propozycji katechetycznej. Nie są oni jedynie biernymi użytkownikami czy też odbiorcami jakiejś usługi, ale są wezwani do tego, by być jednocześnie uczniami i misjonarzami (DK 4). Dalej dokument konsekwentnie podkreśla podmiotowość każdego ochrzczonego w ewangelizacyjnej misji Kościoła (DK 40). Mówiąc o tożsamości katechety zauważa, że wspólnota chrześcijańska, do której należy, jest pierwszym podmiotem towarzyszenia w wierze (DK 111). Katecheta towarzysząc osobom w wierze swoją funkcję spełnia w duch dialogu i służby (DK 142). Do aktywnych podmiotów katechezy dokument zalicza rodziców (DK 124). Dyrektorium nie ogranicza podmiotowości do katechetów, ale rozciąga ją także na katechumenów i katechizowanych. Tę wspólną podmiotowość katechetów i katechizowanych uzasadnia w następujący sposób: „Katecheta, rozumiejąc, że jego rozmówca jest aktywnym podmiotem, w którym w sposób dynamiczny działa łaska Boża, powinien z szacunkiem ułatwiać doświadczenie wiary, w którym nie odgrywa głównej roli (DK148). Cała ta refleksja o podmiotowości ochrzczonych odnosi się także do podmiotowości dorosłych w katechezie, dlatego w tym Dyrektorium po raz pierwszy występuje sformułowanie „katecheza z dorosłymi” (DK 257-268). Wśród kryteriów katechezy z dorosłymi jedno dotyczy wprost ich podmiotowego traktowania. Dokument mówi dobitnie, że dorosłych nie należy rozumieć jako adresatów katechezy, lecz jako pierwszoplanowych uczestników wraz z katechetami. Wynika z tego potrzeba pełnej szacunku akceptacji dorosłego jako osoby, która ma już swoje doświadczenie wiary oraz własne przekonania i jest zdolna w sposób wolny, w dialogu dochodzić do nowych przekonań. 
Śledząc w dokumentach rozwój katechezy dorosłych w aspekcie podmiotu można się pokusić o tezę, że refleksja nad nią w miarę nabywanych przez pół wieku doświadczeń Kościoła wyzwala się od kategorii myślenia pedagogiczno-dydaktycznego i nabiera cech myślenia teologicznego o katechezie.

\section{Od wiary dojrzałej do zjednoczenia z Chrystusem}

Ogólna instrukcja katechetyczna umieszcza katechezę w ramach działalności duszpasterskiej Kościoła i nazywając ją formą działalności kościelnej, wyznacza jej cel ogólny, jakim jest prowadzenie zarówno wspólnoty jak i poszczególnych wiernych do osiągnięcia dojrzałości w wierze (OIK 21). Ten cel pozostaje w ścisłym związku z przedstawieniem treści całego orędzia zbawczego (OIK 38). W kolejnych punktach wyjaśnia, że człowiek dojrzały w wierze odpowiada na wezwanie ewangeliczne, przez które jest skłaniany do nawiązania wspólnoty z Bogiem i braćmi. Realizuje on również w swoim życiu obowiązki związane $\mathrm{z}$ tym powołaniem (OIK 23). Człowiek dojrzały w wierze poznaje tajemnicę zbawienia objawioną w Chrystusie oraz znaki i działanie Boże, które świadczą o wypełnianiu się tajemnicy w historii ludzkiej (OIK 24), potrafi rozpoznać w rożnych okolicznościach zaproszenie Boga, który go wzywa do wypełnienia jego planu (OIK 26), kieruje swoje myśli i pragnienia ku pełni, jaka stanie się jego udziałem w życiu wiecznym królestwa (OIK 29). Zasadniczo cel ogólny postawiony w Instrukcji przed katechetyczną posługą Słowa dotyczy całej katechezy bez względu na wiek jej adresatów.

Z kolei w Dyrektorium ogólnym o katechizacji następuje wyraźny progres w rozumieniu nadrzędnego celu katechezy. Dokument podejmując wypowiedź adhortacji Catechesi tradendae stwierdza, że „ostatecznym celem katechezy jest doprowadzić kogoś nie tylko do spotkania z Jezusem, ale do zjednoczenia, a nawet głębokiej z Nim zażyłości”. Dyrektorium rozumie katechezę jako działanie ewangelizacyjne Kościoła w całości nastawione na rozwijanie komunii z Jezusem Chrystusem. Wychodząc z eklezjalnej natury katechezy podkreśla, że „opierając się na nawróceniu początkowym osoby do Pana Jezusa, wzbudzonym przez Ducha Świętego za pośrednictwem pierwszego głoszenia, katecheza ma na celu dać podstawę temu pierwszemu przylgnięciu i prowadzić je ku dojrzałości (DOK 80). „Komunia z Jezusem Chrystusem, na mocy swej dynamiki, kieruje ucznia do zjednoczenia się z tym wszystkim, z czym głęboko był zjednoczony sam Jezus Chrystus”, z Bogiem Jego Ojcem, z Duchem Świętym, Kościołem i z ludźmi (DOK 81).

W ostatnim z dokumentów katechetycznych cel katechezy został dokładnie określony jak w dokumencie poprzednim. Dyrektorium o katechizacji podaje, że celem katechezy jest doprowadzić kogoś nie tylko do spotkania z Jezusem Chrystusem, ale do zjednoczenia, a nawet głębokiej z Nim zażyłości (DK 75). W podjęcie tego celu wpisuje się katecheza $z$ dorosłymi, traktowana jako osobisty i wspólnotowy proces uczenia się, mający na celu ukształtowanie mentalności wiary. Głównym celem tak 
rozumianej katechezy jest stopniowe kształtowanie i rozwijanie życia w duchu tak, by ewangeliczne przesłanie przyjęte zostało z całą jego przeobrażającą dynamiką, a tym samym mogło oddziaływać na życie osobiste i społeczne. Osiągniecie tego celu stanie się możliwym wówczas, gdy dorosły jest w stanie sam zadbać o własne doświadczenie wiary i pragnie je rozwijać (DK 260).

\section{Od pouczenia $w$ wierze do świadectwa wiary}

Aby zrealizować cel nadrzędny katechezy należy podjąć konkretne zadania. W przypadku Ogólnej instrukcji katechetycznej tak wyznaczonemu celowi odpowiada zadanie ogólne prowadzenia do dojrzałości w wierze (OIK 21). Nie spotykamy dalej w dokumencie osobnego wykazu zadań szczegółowych, ale można je wyczytać w drugim rozdziale Instrukcji, poświęconym katechezie w misji duszpasterskiej Kościoła. Natomiast, gdy chodzi o katechezę dorosłych, to jej zadaniem jest stałe wychowywanie dorosłych w zakresie wiary (OIK 9). Temu celowi odpowiadają szczegółowe zadania, a mianowicie wychowywać do słusznej oceny w świetle wiary zmian społecznych i kulturalnych dzisiejszej społeczności, udzielać odpowiedzi na współczesne pytania, dotyczące spraw religijnych i moralnych, naświetlać relacje jakie zachodzą pomiędzy działaniem doczesnym i działaniem kościelnym, budować rozumowe podstawy wiary (OIK 97). Z przeglądu tych zadań wynika, że są one ukształtowane w odpowiedzi na potrzebę kształtowania dojrzałej wiary ludzi dorosłych. Sytuując się na płaszczyźnie antropologicznej mają pomóc katechizowanym w dokonaniu rozeznania i podejmowaniu właściwych chrześcijaninowi wyborów. $\mathrm{W}$ ich optyce ważne jest, aby człowiek dorosły zachowywał się w sposób godny chrześcijanina we wszystkich sytuacjach, z jakimi się zmierzy w życiu społecznym. Wśród zadań także to ostatnie dotyczące wiary potraktowane zostało na wskroś egzystencjalnie. Podobnie ma się sprawa z zadaniami wytyczonymi przed katechezą osób starszych. Katecheza ta ma bowiem doprowadzić człowieka do właściwej hierarchii celów, pomóc w zrozumieniu sensu życia i śmierci, przygotować ludzi starszych na śmierć, wychowywać starszych do nadziei nadprzyrodzonej (OIK 95).

Dyrektorium ogólne o katechizacji przyjmując za cel komunię z Jezusem Chrystusem dla całej katechezy wyznacza zadania ściśle powiązane z treścią katechezy (DOK 84). Dyrektorium stwierdza, że „zadania katechezy odpowiadają nauczaniu różnych wymiarów wiary, ponieważ katecheza jest integralną formacją chrześcijańską «dotyczącą wszystkich elementów życia chrześcijańskiego», jak czytamy w adhortacji Catechesi tradendae. Na mocy swego dynamizmu wewnętrznego wiara wymaga, by była znana, celebrowana, przeżywana i wyrażana w modlitwie" (tamże). W myśl II Soboru Watykańskiego „...ona to oświeca i wzmacnia wiarę, karmi życie wedle ducha Chrystusowego, doprowadza do świadomego i czynnego uczestniczenia w misterium liturgicznym i pobudza do działalności apostolskiej" (GE 4). Podstawowymi zadaniami katechezy są: rozwijanie wiary, wychowanie 
liturgiczne, formacja moralna, nauczanie modlitwy, wychowanie do życia wspólnotowego, wychowanie do misji (DOK 85-86). Co się zaś tyczy katechezy dorosłych dokument podkreśla ponownie, że katecheza dorosłych powinna zaproponować wiarę chrześcijańską w jej integralności, autentyczności i systematyczności, stawiając na pierwszym planie głoszenie zbawienia, oświecając dzisiejsze trudności, pokazując wpływ duchowy i moralny orędzia, wprowadzając do chrześcijańskiego czytania Pisma Świętego i do praktyki modlitwy. Dyrektorium to odnosi się do promulgowanego wcześniej Katechizmu Kościoła Katolickiego jako podstawowego źródła treści. Gdy zaś chodzi o wytyczenie zadań to zapożycza je z Ogólnej instrukcji katechetycznej, dołączając dwa nowe. Jedno z nich brzmi: popierać formację i dojrzewanie życia w Duchu Chrystusa zmartwychwstałego za pomocą sakramentów, dni skupienia, kierownictwa duchowego. Drugie z kolei dotyczy odpowiedzialności za misję Kościoła oraz umiejętności dawania świadectwa chrześcijańskiego w społeczeństwie. Wspólnota eklezjalna jak i wspólnota ludzka ma wspomagać człowieka dorosłego w odkrywaniu, dowartościowywaniu i aktualizowaniu tego, co otrzymał za pośrednictwem natury i łaski (DOK 175) ${ }^{12}$.

Postawione przed katechezą w Dyrektorium o katechizacji zadania dotyczą najpierw całej katechezy i są to: prowadzić do poznania wiary, wtajemniczyć w sprawowanie Misterium, formować do życia w Chrystusie, uczyć modlitwy, wprowadzać do życia wspólnotowego (DK 79-89). Tak zredagowane i rozwinięte niosą w sobie dynamizm ewangelizacyjny. $\mathrm{O}$ dynamice tych zadań na pozór powtórzonych za Dyrektorium ogólnego o katechizacji świadczy nowy język zastosowany w ich sformułowaniu w nowszym Dyrektorium. Tak więc zamiast mówić „rozwijanie poznania wiary” używa się sformułowania „prowadzić do poznania wiary”, zamiast: „wychowanie liturgiczne” - „wtajemniczać w sprawowanie Misterium”, zamiast „formacja moralna” - „formować do życia w Chrystusie; „wychowanie do modlitwy” zastąpiono słowami „uczyć modlitwy”, „wychowanie do życia wspólnotowego słowami „wprowadzać do życia wspólnotowego”. W Dyrektorium o katechizacji umieszczono przy zadaniach komentarze poszerzające ich znaczenie. Na przykład, przy zadaniu „prowadzić do poznania wiary”, chodzi o to, by nie lekceważyć treści wiary w formacji integralnej i nie zastępować ich wyłącznie doświadczeniem wiary. Dając takie wyjaśnienie dokument wskazuje na potrzebę zachowania równowagi pomiędzy poznaniem a doświadczeniem wiary. Ponadto ostatnie Dyrektorium odpowiedzialnymi za podjęcie zadań katechezy czyni wszystkich uczestników katechezy. Czytamy w nim, że rozwijanie wiary otrzymanej na chrzcie jest osobistym zadaniem każdego dorosłego, jeśli zależy mu na kształtowaniu własnej tożsamości. Wynika to $\mathrm{z}$ faktu, że człowiek dorosły konfrontowany z obowiązkami rodzinnymi i społecznymi wciąż staje wobec dylematów, które powinien

\footnotetext{
12 Por. P. Tomasik, Charakterystyka Dyrektorium ogólnego o katechizacji, w: Katecheza Kościoła w świetle Dyrektorium ogólnego o katechizacji, Warszawa 1999, s. 55-56.
} 
rozwiązywać. Katecheza ma mu pomóc, by wykształcił w sobie duchową mądrość, zdolną zmierzyć się z wszystkimi wyzwaniami, jakie niesie codzienność (DK 259).

Oprócz wymienionych wyżej zadań ogólnych przed katechezą dorosłych zostały postawione zadania szczególne, skorelowane z sytuacja osobistą dorosłego w wymiarze wiary. W zależności od tego czy dorosły jest ochrzczonym bądź nie, zaangażowanym w wierze bądź uczestniczącym w życiu wspólnoty chrześcijańskiej sporadycznie, wyznającym poprawnie wiarę katolicką bądź pogubionym w wyznawanym przez Kościół Credo, gotowym do dawania świadectwa wiary bądź nieprzygotowanym Dyrektorium wyznacza następujące zadania: budzenie wiary, oczyszczenie wiary, ożywianie wiary, pomoc w dzieleniu się wiarą i dawaniu świadectwa (DK 261). Zadanie „budzenia wiary” ma pomóc w ponownym podjęciu doświadczenia wiary i wykorzystaniu własnego jej potencjału w celu ukształtowania motywacji do życia zgodnego z jej wymogami. „Oczyszczenie wiary” polega na usunięciu z niej błędnych wyobrażeń, rozpoznaniu własnych ograniczeń i wejście na drogę poszukiwania bardziej autentycznych ujęć wiary w dążeniu do pełni życia. „Ożywianie wiary” to coraz lepsze wtapianie się we wspólnotę Kościoła, kształtowanie dojrzałej chrześcijańskiej świadomości zdolnej uzasadnić własną wiarę i otwartej na rozumny dialog ze współczesną kulturą. „Pomoc w dzieleniu się wiarą i dawaniu świadectwa wiary” poprzez przygotowanie przestrzeni do dzielenia się i posługi w Kościele i w świecie (tamże).

W tak wyznaczonych katechezie z dorosłymi zadaniach wyczuwa się nową perspektywę. Nie tyle skupiają się one na wychowaniu dorosłego we wszystkich możliwych wymiarach i dostarczeniu mu koniecznych narzędzi do kształtowania wiary dojrzałej w ogólności, ile na przyjściu z pomocą na kolejnych etapów procesu rozwoju wiary, które odpowiadają dorosłym w konkretnych sytuacjach.

\section{Doprecyzowywanie kryteriów}

Dla określenia tożsamości katechezy dorosłych ważne jest sformułowanie kryteriów, jakim powinna odpowiadać. W pierwszym dokumencie kryteria te zwane też „normami” zostały odniesione do treści katechezy ogólnie pojętej (OIK 37-46). W związku z celem katechezy rozumianym jako doprowadzenie do wiary dojrzałej kryterium podstawowym jest troska o przekazanie całego orędzia chrześcijańskiego (37-38); ponadto w katechezie obowiązuje zasada chrystocentryzmu i teocentryzmu trynitarnego (40-41), zasada wierności Bogu i człowiekowi (42). Kolejne kryteria to hierarchia prawd (43), historyczny charakter tajemnicy zbawienia (44), źródła katechezy (45), metody dostosowane do różnych warunków (46). W Ogólnej instrukcji katechetycznej nie zostały podane kryteria odnoszące się do katechezy dla dorosłych. Te jednak odnoszące się do treści oraz metody katechezy kształtowanej 
w myśl nauki soborowej w wielu punktach mogłyby być z pożytkiem zaadaptowane do katechezy dorosłych ${ }^{13}$.

W kolejnym dokumencie katechetycznym uznano za ważne, aby sformułować kryteria odpowiadające katechezie dorosłych (DOK 173-174). Zostały one odniesione najpierw do podmiotu katechezy, jaki stanowią dorośli, którzy z jednej strony stoją przed zadaniem doprowadzenia do dojrzałości zarodka wiary danego im przez Boga, a $z$ drugiej jako osoby pełniące różne role społeczne wystawione są na zmiany, nierzadko poważne kryzysy. $Z$ tych bowiem tytułów wiara ich powinna być stale oświecana, rozwijana i chroniona (DOK 173). Dokument wskazuje na potrzebę określenia typowych cech chrześcijanina dojrzałego w wierze i dostosowania do nich treści, formy i metody. Ponadto zaznacza konieczność pochylenia się w sposób szczególny nad tożsamością katechety dorosłych oraz formacją tych, którzy są odpowiedzialni za katechezę dorosłych we wspólnocie. Tu odwołuje się do szerokiego omówienia tematu w dokumencie Katecheza doroslych we wspólnocie chrześcijańskiej (KDWK 33-84). Na podstawie tegoż dokumentu również formułuje cztery kryteria katechezy dorosłych (por. tamże 26-30), mające zapewnić jej autentyzm i skuteczność. Pierwsze trzy kryteria odnoszą się do podmiotu i są to: zainteresowanie się adresatami w ich sytuacjach dorosłych, jako mężczyzn i kobiet, zauważenie świeckiego stanu dorosłych, dostrzeganie wagi włączenia do wspólnoty. Ostatnie, czwarte kryterium, dotyczy organicznego programu duszpasterskiego dla dorosłych (DOK 174). Ze sformułowania kryteriów wynika, że choć katecheza stara się być wierna człowiekowi, interesując się jego bogactwem duchowym i kulturowym, to jednocześnie myśli o dorosłym jako adresacie katechezy. Cenne jest natomiast dostrzeżenie godności człowieka świeckiego, wynikającej z przyjętego sakramentu chrztu i świeckiego charakteru jego posługi. Ponadto dokument podkreśla wagę wspólnoty jako miejsca przyjęcia i wsparcia dla dorosłego. Katecheza dorosłych powinna również wychowywać do liturgii i formować do posługi potrzebującym braciom.

W ostatnim Dyrektorium (262) odpowiednikami celu katechezy, jakim jest również komunia z Jezusem Chrystusem są kryteria o zabarwieniu ewangelizacyjnym (DK 262). Dokument wymienia je w następującej kolejności: katecheza musi być wyrazem wspólnoty kościelnej, proponować wartościowe doświadczenia życia wiarą, dorośli nie są adresatami, ale pierwszoplanowymi uczestnikami wraz z katechetami, katecheza powinna uwzględniać doświadczenie mężczyzn i kobiet, koordynacja katechezy z duszpasterstwem rodziny i młodzieży. Wśród tych kryteriów na szczególną uwagę zasługuje to, które odnosi się do określenia roli dorosłych w katechezie. Mówi ono, że: „dorosłych nie należy rozumieć jako adresatów katechezy, lecz jako jej pierwszoplanowych uczestników wraz z samymi katechetami. Konieczna jest zatem pełna szacunku akceptacja dorosłego jako osoby, która ma

13 Por. D. Kurzydło, Koncepcja..., tamże, s. 267-268. 
już pewne doświadczenia i przekonania, także w odniesieniu do wiary i jest zdolna w sposób wolny, w dialogu, dochodzić do nowych przekonań (tamże). Podobnie jak w Dyrektorium ogólnym o katechizacji ostatni dokument katechetyczny Kościoła powszechnego zwraca uwagę na osobę katechety. Powinien on pełnić wobec dorosłych rolę towarzysza, a zarazem wychowawcy, który potrafi wesprzeć powierzonych sobie w procesach rozwoju osobistego (DK 263).

\section{Stały rozwój form katechezy}

Gdy chodzi o formy katechezy to jawią się one przede wszystkim jako odpowiedź na konkretne potrzeby człowieka dorosłego dbającego o wdrożenie czy też ciągły rozwój wiary. Już w Ogólnej instrukcji katechetycznej zauważamy taką tendencję. Wśród form wymienia się na pierwszym miejscu katechezę inicjacji chrześcijańskiej bądź też katechumenatu. Chodzi zatem o tych dorosłych, którzy są już ochrzczeni, a nie rozwinęli swojej wiary bądź osoby, które proszą o przyjęcie ich do wspólnoty Kościoła. Druga forma dotyczy tych, którzy są zaangażowani w jakąś formę apostolstwa i potrzebują pogłębienia znajomości orędzia chrześcijańskiego. Jest też mowa o katechezie okolicznościowej z racji ważniejszych wydarzeń w życiu, takich jak małżeństwo, chrzest dzieci, pierwsza Komunia czy bierzmowanie, bądź też innych sytuacji życiowych, jak np. choroba. W powyższym dokumencie proponuje się katechezę z racji zmiany warunków życia, tak jak np. rozpoczęcie pracy, służby wojskowej, migracji, itp. Nowo dostrzeżoną w Kościele potrzebą jest katecheza kierowana do turystów. W końcu dokument sugeruje możliwość katechezy z racji szczególnych wydarzeń w życiu Kościoła lub społeczności świeckiej. Wszystkie podane tu formy nie zmniejszają konieczności ustanawiania cyklów katechetycznych, które mają na względzie systematyczne studium całego orędzia chrześcijańskiego (OIK 96) ${ }^{14}$.

Podobne podejście do form katechezy dorosłych reprezentuje Dyrektorium ogólne o katechizacji, odwołując się wprost do tych, które zaprezentowane zostały w Instrukcji. Powtarzając je, czasami wzbogaca ich rozumienie bądź poszerza ich zakres. Tak więc mówiąc o katechezie inicjacji i katechumenacie wskazuje na Obrzędy chrześcijańskiego wtajemniczenia dorostych, które taką formację mogą wspomóc. Jako nową formę wymienia katechezę dla ludu Bożego w ciągu roku liturgicznego lub w szczególnej postaci, jaką są misje. Przed wskazaniem katechizowania zaangażowanych w apostolstwo świeckich wymienia również tych, którzy odpowiedzialni są we wspólnocie za katechezę, czyli katechetów. Na zakończenie dokument podkreśla, podobnie jak poprzedni, potrzebę systematycznej, organicznej

\footnotetext{
14 Por. A. Potocki, Katecheza dorostych $w$ przemianie, w: K. Misiaszek (red.), Katecheza dorostych we wspólnocie Kościoła, Warszawa 2002, s. 73.
} 
i stałej katechezy, dla której wymienione wcześniej formy mają być jedynie uzupełnieniem (DOK 176).

W Dyrektorium o katechizacji pojawia się oryginalne ujęcie form katechezy. Podobnie jak wszystkie dotąd elementy konstytuujące katechezę, również formy zostały dostosowane w do poziomu wiary, która ma podlegać rozwojowi w życiu różnych osób. Jej wyznacznikiem jest doświadczenie. Dokument mówi zatem o katechezie $\mathrm{w}$ formie wprowadzenia do wiary poprzez doświadczenie katechumenatu, a także o katechezie jako ponownym wprowadzeniu do wiary dla już ochrzczonych, którzy nie ukończyli drogi wprowadzenia do wiary. W tym kluczu mówi również o katechezie $\mathrm{w}$ formie odkrywania wiary przez tzw. oddalonych od wiary. Kolejna forma to katecheza głoszenia wiary w środowisku życia, pracy, rozrywki albo przy okazji różnego rodzaju przejawów pobożności ludowej i pielgrzymek do sanktuariów. Inna sugerowana forma odnosi się do narzeczonych przed zawarciem sakramentu małżeństwa, czy przy okazji przystępowania dzieci do sakramentów. Potrzebna jest również katecheza liturgiczna w celu świadomego uczestniczenia w obrzędach Kościoła. Dalej proponuje się katechezę o tematyce moralnej, kulturalnej lub społeczno-politycznej, zmierzającą do inspirowanego wiarą udziału wiernych w życiu społecznym. Na końcu wymieniona została katecheza osób zaangażowanych w duszpasterstwo, stanowiąca sposobność szczególnie sprzyjającą rozwojowi wiary (DK 264). Dokument, nawiązując do adhortacji Evangelii gaudium (EG 127-129), zwraca również uwagę na udział w formacji chrześcijańskiej stowarzyszeń, ruchów i grup kościelnych, które przedstawiają życie chrześcijańskie jako osobiste i egzystencjalne spotkanie z żywym Jezusem Chrystusem. Małe grupy, ułatwiające wymianę doświadczeń życiowych i tworzenie braterskich i przyjacielskich więzi, są cenną okazją do przepowiadania wiary przez jednych drugim (DK 265).

Analizując posoborowe dokumenty katechetyczne Kościoła powszechnego dostrzec w nich można stały rozwój koncepcji katechezy dorosłych, wpisującej się w ewolucję myśli katechetycznej po II Soborze Watykańskim. Wyrazem tych przemian są na nowo formułowane cele, zadania, kryteria i formy katechezy prowadzonej wśród dorosłych. Jak mogliśmy zauważyć, doskonalą się również kryteria i formy tejże posługi słowa. Najbardziej charakterystycznym jest to, że Kościół odchodzi od pragmatycznych ujęć formacji świeckich i steruje w kierunku integralnej katechezy osób dorosłych. W katechezie nie chodzi bowiem najpierw o sprawne funkcjonowanie duszpasterstwa, ale o budzenie wiary żywej, oczyszczanie jej, stałe ożywiane i gotowość do dawanie świadectwa. Dobra praktyka duszpasterska i owocna obecność dorosłych w świecie jest takim podejściem w katechezie uwarunkowana.

Słowa kluczowe: katecheza dorosłych, formacja dorosłych, podmiot, cel, zadania, formy, kryteria katechezy dorosłych. 


\begin{abstract}
A need for adult-addressed catechesis mentioned in the documents of the Vatican Council II, was brought up in three post-conciliar Directories of the universal Church, namely in General Catechetical Directory of 1971, General Directory for Catechesis of 1997 and Directory for Catechesis of 2020. One can observe that the overall vision of adult-addressed catechesis is shaped on the basis of those documents and it is also subject to constant evolution. This article attempts to grasp the evolution of catechesis based on its essential elements, such as the subject, purpose, tasks and form. The essay makes also allowances for the criteria governing adult-addressed catechesis. After analysis it is evident that each Directory bears the legacy of church documents that preceded it. The evolution of the catechesis in question is predominantly visible in the adult-centred approach in catechesis.

Keywords: Adult-addressed catechesis, adult formation, the subject, purpose, tasks, forms, criteria governing adult-centred catechesis.
\end{abstract}

\title{
Riassunto
}

Segnalata nei documenti del Concilio Vaticano II necessità della catechesi degli adulti, è stata ripresa nei tre Direttori catechetici postconciliari della Chiesa universale, cioè nell'Istruzione Catechistica Generale (1971), nel Direttorio Generale sulla Catechesi (1997) e nel Direttorio sulla catechesi (2020). Questi documenti mettono le basi per la visione complessiva della catechesi degli adulti che, come è facile intuire, è soggetta a un costante cambiamento. Nel presente articolo si è cercato di comprendere l'evoluzione della catechesi in base ai suoi elementi costitutivi, come il soggetto, lo scopo, i compiti e la forma. Lo studio da ascolto anche ai criteri della catechesi per gli adulti. Dall'analisi di questi contenuti emerge che ogni Direttorio porta con sé compimento dei precedenti documenti ecclesiali. L'evoluzione della catechesi per gli adulti è più visibile nel trattamento soggettivo di un adulto nella catechesi.

Parole chiavi: Catechesi per gli adulti, formazione degli adulti, soggetto, scopo, compiti, forme, criteri per la catechesi degli adulti.

\section{Bibliografia}

Dziekoński S. (red.), Przesłanie dokumentów katechetycznych Kościoła w Polsce, Warszawa 2003.

Kongregacja ds. Duchowieństwa, Ogólna instrukcja katechetyczna, 1971.

Kongregacja ds. Duchowieństwa. Dyrektorium ogólne o katechizacji, Poznań 1998.

Kubik W. (red.), Katecheza po Soborze Watykańskim II w świetle dokumentów Kościoła,

Warszawa 1985, cz. 1-2.

Kurzydło D. (red.), Katechetyk $i$ wychowawca. Księga jubileuszowa dedykowana ks. prof. Kazimierzowi Misiaszkowi SDB, Warszawa 2019, s. 55-274.

Kurzydło D., Koncepcja katechezy dorosłych we współczesnych dokumentach Kościoła. Kraków 2003.

Marek Z. (red.), Katecheza Kościoła w świetle Dyrektorium ogólnego o katechizacji, Kraków 1999. 
Międzynarodowa Rada ds. Katechezy, Katecheza dorosłych we wspólnocie chrześcijańskiej, Kraków 2001.

Misiaszek K. (red.), Katecheza dorostych we wspólnocie Kościoła, Warszawa 2002.

Młyńska E,. Kryteria doboru metod w katechezie dorosłych, w: Misiaszek K. (red.), Katecheza dorosłych, Tarnów 2009, s. 539-573.

Papieska Rada ds. Krzewienia Nowej Ewangelizacji, Dyrektorium o katechizacji, Kielce 2020.

\section{O autorze}

Elżbieta Młyńska - dr katechetyki KUL. Długoletni wykładowca katechetyki w Papieskim Wydziale Teologicznym w Warszawie. Sekcja Świętego Jana Chrzciciela, Studium Teologii w Białymstoku oraz w Archidiecezjalnym Wyższym Seminarium Duchownym w Białymstoku. Studiowała w Instytucie Katechezy Dorosłych w Uniwersytecie Katolickim w Lille (Francja). Jest animatorem i promotorem katechezy dorosłych Mess'AJE w Polsce oraz pełni funkcję wiceprezesa Stowarzyszenia Mess'AJE Polska. Należy do Stowarzyszenia Katechetyków Polskich. W badaniach naukowych zajmuje się katechezą parafialną i katechezą dorosłych. 